\title{
Growth and development of soybean roots according to planting management systems and irrigation in lowland areas
}

\author{
Crescimento e desenvolvimento de raízes de soja em função \\ do manejo de implantação e da irrigação em área de várzea
}

\author{
Gerson Meneghetti Sarzi Sartori ${ }^{*}$ Enio Marchesan ${ }^{\mathrm{I}}$ Ricardo De David $^{\mathrm{I}}$ \\ Fernando Teixeira Nicoloso ${ }^{I I}$ Márcio Renan Weber Schorr ${ }^{I}$ \\ Alberto Cargnelutti Filho ${ }^{I}$ Gabriel Donato ${ }^{\mathrm{I}}$
}

ABSTRACT

The presence of a compacted soil layer near the ground surface in paddy fields may limit the growth and development of soybean roots. The objective of this study was to evaluate different planting management systems and irrigation on growth and development of soybean root systems in lowland area. The experiment was carried out in 2013/14 and 2014/15 crop seasons in randomized complete block design with factorial treatment (3x2), with four replications. The treatments consisted of different planting management systems: sowing with double disc (A1); sowing with shank (A2) and deep tillage + sowing with double disc (A3), and irrigation: irrigated (D1) and non irrigated (D2). Planting management systems and irrigation influenced the growth of soybean roots. When double disc was used, roots have lower growth and increase in diameter. Use of shanks and deep tillage provide increased growth and development of soybean roots and greater depth distribution. An additional $55 \mathrm{~mm}$ of irrigation during the V4 soybean development stage provides increased surface area and root volume in when the soil moisture reaches values below $60 \%$ of field capacity.

Key words: Glycine max L., compacted layer, shank, deep tillage, root system.

\section{RESUMO}

A presença de uma camada compactada próxima à superficie do solo em áreas de várzeas pode limitar o crescimento $e$ desenvolvimento das raizes de soja. O objetivo do trabalho foi avaliar diferentes manejos de implantação e irrigação no crescimento e desenvolvimento do sistema radicular de soja em área de várzea. O experimento foi realizado nas safras 2013/14 e 2014/15 no delineamento experimental de blocos ao acaso em esquema fatorial (3x2), em faixa, com quatro repetições. Os tratamentos constaram de diferentes manejos de implantação da cultura: semeadura com disco duplo desencontrado (A1); semeadura com haste sulcadora (A2) e escarificação do solo + semeadura com disco duplo desencontrado (A3), e de irrigação: com irrigação (D1) e sem irrigação (D2). Os manejos de implantação e a irrigação influenciaram no crescimento das raizes de soja. No disco duplo, as raizes apresentam menor crescimento $e$ aumento do diametro. Os manejos com haste sulcadora e escarificação do solo proporcionam maior crescimento e desenvolvimento de raizes de soja e maior distribuição em profundidade. Uma irrigação suplementar de $55 \mathrm{~mm}$ no estádio V4 de desenvolvimento das plantas de soja proporciona aumento da área superficial e do volume de raizes em soja, quando a umidade do solo atinge valores abaixo de $60 \%$ da capacidade de campo.

Palavras-chave: Glycine max L., camada compactada, haste sulcadora, escarificação do solo, sistema radicular.

\section{INTRODUCTION}

Cultivation of soybean has been occupying a substantial space in irrigated rice areas of the state of Rio Grande do Sul - Brazil. However, most of these areas are flat and prone to the formation of a hydromorphic environment (BORGES et al., 2004), which makes drainage of the area difficult. Moreover, there is a compacted subsurface soil layer due to tillage, which causes the soil disruption, influencing the amount of macropores (VALICHESKI et al., 2012) and also total porosity (DRESCHER et al., 2011).

In addition to these factors, an increase in soil bulk density and penetration resistance (SPERA et al., 2012) also occurs; thereby, reducing root depth in the soil (OLIVEIRA et al., 2012). Thus, the compacted soil layer can affect the soil-air-water

\footnotetext{
'Departamento de Fitotecnia, Centro de Ciências Rurais (CCR), Universidade Federal de Santa Maria (UFSM), 97105-900, Santa Maria, RS, Brasil. E-mail: gersonmss@yahoo.com.br. "Corresponding author.

IIDepartamento de Biologia, Universidade Federal de Santa Maria (UFSM), Santa Maria, RS, Brasil.
} 
relationship, limiting growth and development of the root system (CARDOSO et al., 2006).

According QUEIROZ-VOLTAN et al. (2000), the soybean root system under normal cultivation conditions, is distributed almost entirely within the first $15 \mathrm{~cm}$ of soil. However, when there is any physical limitation of the soil, there may be a reduction in root growth. According to OLIVEIRA et al. (2012), soil compaction increases the diameter of soybean roots, and this inhibits its development.

In this context, it is essential to assess planting management systems that reduce the compacted soil and consequently promote higher root growth and development of soybean plants. Among the available managements, deep tillage and sowing with shank have provided positive effects on soil decompression within the crop row (DRESCHER et al., 2011). Irrigation is also an important tool because the water content in the soil directly interferes in soybean roots (HOSSNE et al., 2015).

As a result, this study aimed to evaluate the effect of different planting management systems and irrigation on growth and development of soybean root systems in a lowland area.

\section{MATERIALS AND METHODS}

The experiment was carried out during the 2013/14 and 2014/15 crop seasons in the experimental lowland area of the Federal University of Santa Maria (UFSM), in southern Brazil, in soil classified as Albaqualf (SOIL SURVEY STAFF, 2014). For each crop season, the experiment was set up at a different location within the experimental area.

The soil at the experimental area had the following physical and chemical characteristics to the 30 days before sowing: clay $=25 \% ; \mathrm{pH}_{\text {water }}(1: 1)=$ 5.4; $\mathrm{P}=18 \mathrm{mg} \mathrm{dm}^{-3} ; \mathrm{K}=60 \mathrm{mg} \mathrm{dm}^{-3} ; \mathrm{Ca}=5.3 \mathrm{cmol}_{\mathrm{c}}$ $\mathrm{dm}^{-3} ; \mathrm{Mg}=2.4 \mathrm{cmol}_{\mathrm{c}} \mathrm{dm}^{-3}$ and organic matter $(\mathrm{OM}) \stackrel{\mathrm{c}}{=}$ $2.0 \%$ for the $2013 / 14$ crop season and; clay $=26 \%$; $\mathrm{pH}_{\text {water }}(1: 1)=5.4 ; \mathrm{P}=15.3 \mathrm{mg} \mathrm{dm}^{-3} ; \mathrm{K}=44 \mathrm{mg} \mathrm{dm}-3$; $\mathrm{Ca}=8.3 \mathrm{cmol}_{\mathrm{c}} \mathrm{dm}^{-3} ; \mathrm{Mg}=3.1 \mathrm{cmol}_{\mathrm{c}} \mathrm{dm}^{-3}$ and $\mathrm{OM}$. $=$ $2.0 \%$ for the $2014 / 15$ crop season.

The experiment followed a randomized strip-block design in a factorial scheme $(3 \times 2)$, with strip plots for both factor $\mathrm{A}$ and for factor $\mathrm{D}$, with four replications. The factor A was composed of different planting management systems: sowing with a double disc (A1); sowing with a shank (A2) and deep tillage + sowing with double discs (A3). The D factor was: irrigated (D1) and non irrigated (D2).

Deep tillage was carried out at a depth of $25 \mathrm{~cm}$ at 45 prior to sowing for the $2013 / 14$ crop season and 19 days prior to sowing for the 2014/15 season. The working depth was approximately $18 \mathrm{~cm}$ for the shank and $10 \mathrm{~cm}$ for the double discs. Sowing took place on November $7^{\text {th }}$ and $14^{\text {th }}$ of 2013 and 2014, respectively, using a fertilizer seeder. Due to $245 \mathrm{~mm}$ rainfall two days after sowing (2013/14), re-sowing took place on November $26^{\text {th }}, 2013$. The soybean cultivar used was the 'BMX Tornado RR' with 26 seeds $\mathrm{m}^{-2}$, and $0.5 \mathrm{~m}$ distance between rows.

Fertilization at sowing as well as additional crop treatments was performed according to the technical indications for crop (EMBRAPA, 2012). Border irrigation was performed when the average soil moisture was at $58 \%$ of field capacity in the $0-20 \mathrm{~cm}$ layer. During the experiment $55 \mathrm{~mm}$ irrigation was performed in the V4 stage of the plants, according to scale (FEHR \& CAVINESS, 1977), for the 2013/14 crop.

The soil penetration resistance was evaluated. The evaluation was conducted at the sowing line in the $0-20 \mathrm{~cm}$ layer using a digital Falker $^{\circledR}$ PLG 1020 penetrometer at the V6 growth stage of plants.

To evaluate the root systems, at the V6 and R3 growth stages, five plants were collected per repetition in sequence at the sowing line using a 40x40x25 (length, width and depth) soil monolith. After the collection, the root system was separated from shoot and soil by washing with water. After washing, the two plants from the extremities of the monolith were discarded, and only the three plants at the center were scanned using a Epson Expression ${ }^{\circledR}$ 11000XL scanner and analyzed using the software WinRhizo ${ }^{\circledR}$. The values obtained were: root length $(\mathrm{cm})$, projected area $\left(\mathrm{cm}^{2}\right)$, surface area $\left(\mathrm{cm}^{2}\right)$, average diameter $(\mathrm{mm})$, total volume $\left(\mathrm{cm}^{3}\right)$, number of tips and number of root forks.

After these assessments, using the same root, dry mass was analyzed by drying in an oven with forced air circulation at a temperature of $65^{\circ} \mathrm{C}$ until constant weight, after which mass was verified using a precision scale. In the R5 stage, evaluation of dry mass was performed in two soil layers: $0-10$ and $10-20 \mathrm{~cm}$. Samples were collected by soil monoliths of $20 \times 20 \times 10 \mathrm{~cm}$ (length, width and depth) in each layer containing the roots of two plants. After collection, the root system and soil were separated by washing with water and then oven dried to obtain the dry mass, with the results expressed in $\mathrm{mg} \mathrm{cm}^{-3}$ of soil.

The data were submitted to the assumptions of the mathematical model (normality and homogeneity of variances). Analysis of variance 
was performed using the $\mathrm{F}$ test and means, when significant were compared by Tukey test at $5 \%$ probability of error.

\section{RESULTS AND DISCUSSION}

In both crop seasons, the soil in which the experiment was performed had penetration resistance above $2 \mathrm{MPa}$ at layer 7 to $15 \mathrm{~cm}$ (Figure 1A, B). According to BOTTA et al. (2010) and BORTOLUZZI et al. (2014), values of soil penetration resistance as high as $2 \mathrm{MPa}$ are considered to be critical to the growth and development of plant roots. Both deep tillage and shank reduced values of soil penetration resistance at the sowing line to below
$1 \mathrm{MPa}$ and 1.5MPa for the 2013/14 and 2014/15 crop seasons, respectively. Use of double discs resulted in a smaller decrease in soil penetration resistance; thereby, maintaining the presence of the compacted soil layer in the sowing line, since the resistance to penetration is used as an indication of the degree of soil compaction (BEULTER \& CENTURION, 2004).

Regarding the dry mass of roots in the V6 and R3 growth stages, there was no interaction between the planting management system and irrigation (Table 1). Deep tillage and sowing with shank provided the highest amount of dry matter in soybean roots in V6 and R3 growth stages in the 2013/14 crop season and in R3 in the 2014/15 season; there were no effects linked to irrigation. In

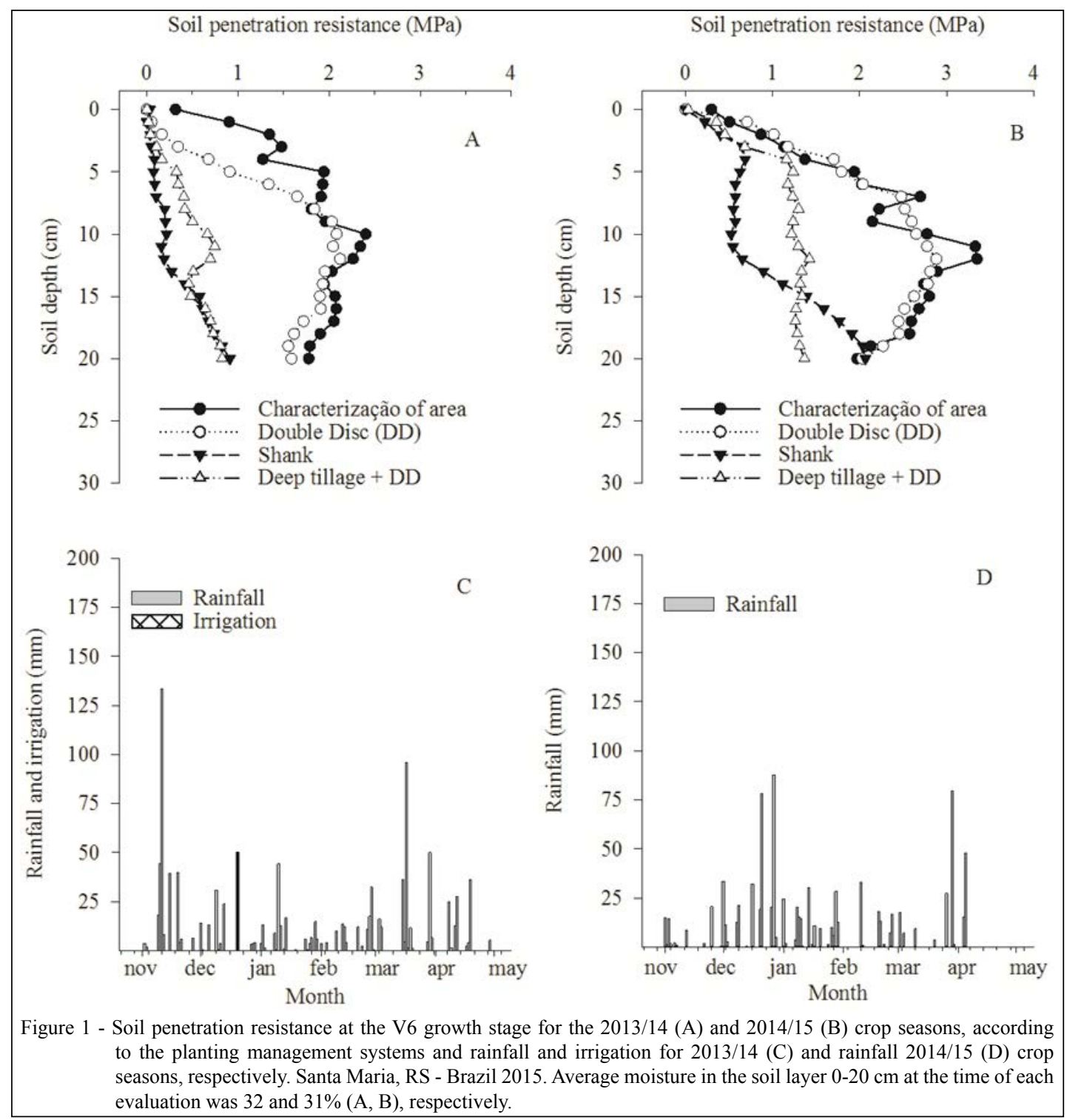

Ciência Rural, v.46, n.9, set, 2016. 
Table 1 - Root dry mass ( $\left.\mathrm{mg}_{\text {plant }} \mathrm{t}^{-1}\right)$ and root dry mass $\left(\mathrm{mg} \mathrm{cm}^{-3}\right.$ soil) of soybean plants ('BMX Tornado RR' cultivar) in two soil depths (D) according to the planting management systems and irrigation. Santa Maria, RS - Brazil. 2015.

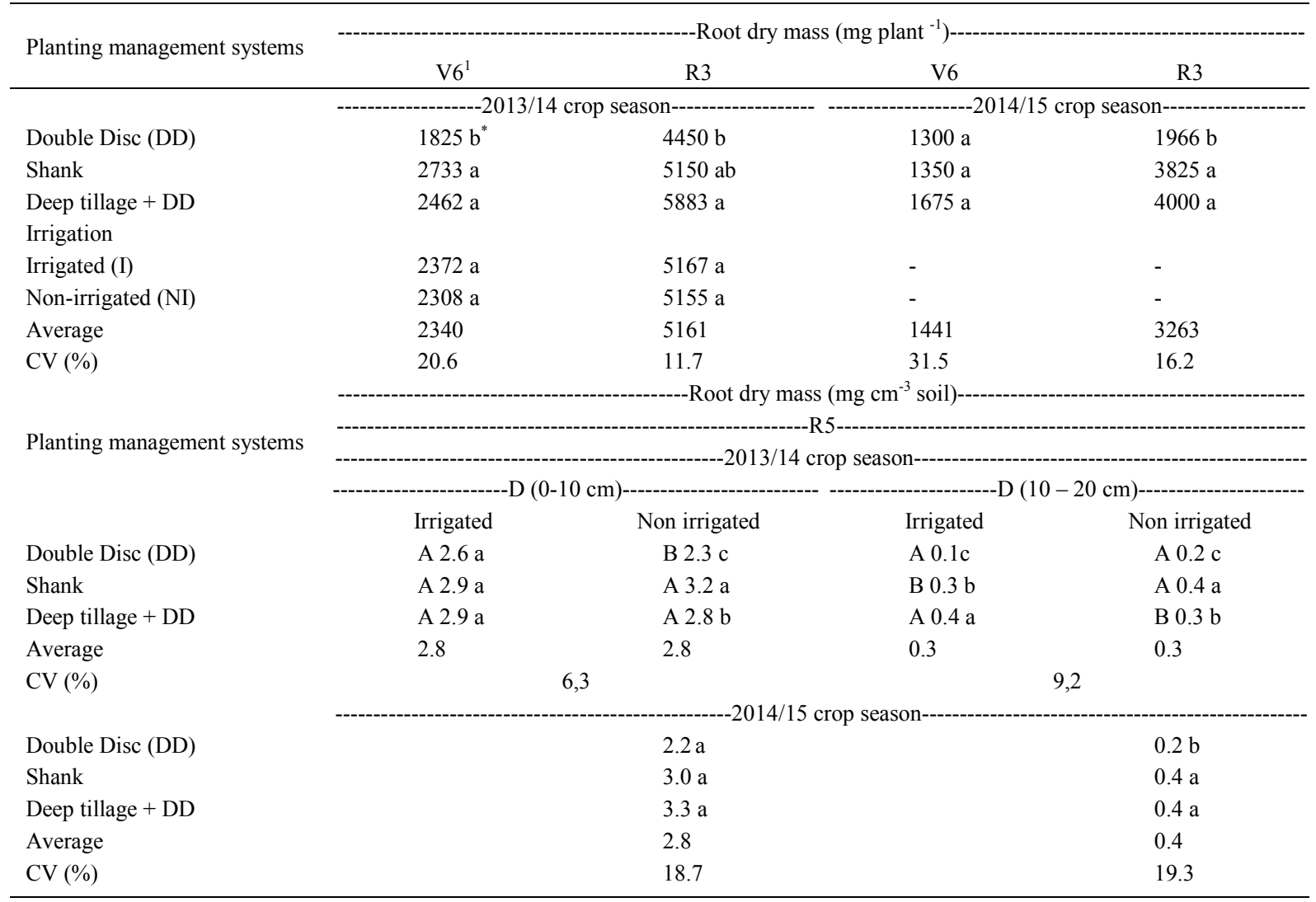

* Means preceded by the same capital letter in line and followed by same letter in the column do not differ by Tukey test at $5 \%$ probability. ${ }^{1}$ plant development stage.

the evaluation at the R5 stage, there was interaction between the planting management systems and irrigation in the $2013 / 14$ crop season. According to the results $94 ; 90$ and $89 \%(2013 / 14$ season) and $92 ; 88$ and $89 \%(2014 / 15$ season) of the total assessed roots were concentrated in the $0-10 \mathrm{~cm}$ layer when using double discs, shank and deep tillage, respectively. However, in the $10-20 \mathrm{~cm}$ layer, in both crop seasons, there was a higher concentration of roots when sowing with shank and deep tillage when compared to the double discs, indicating further deepening the roots in these types of soil management. Another important result is that, especially in the layer subjected to greater stress from the root system $(0-10 \mathrm{~cm}$ layer) irrigation promoted greater dry mass of roots in the double disc system in the 2013/14 crop season.

These results support the studies of BOTTA et al. (2010), which reported greater root growth of soybean in the topsoil with increasing soil penetration resistance. The greatest growth and roots depth in planting management systems using shank and deep tillage may be associated with greater reduction in soil penetration resistance at the sowing line, as seen in figures $1 \mathrm{~A}$ and $1 \mathrm{~B}$. NUNES et al. (2015) evaluated the effect of sowing maize using three shank depths, and reported that working the soil with a shank at $17 \mathrm{~cm}$ resulted in an increase in soil macroporosity and total porosity and reduced penetration resistance, resulting in greater dry mass and root length, growth at greater soil depths.

Total root length, diameter and number of root forks did not differ among planting management systems; only the effect of irrigation was observed which resulted in greater root length, observed in V6 in the 2013/14 crop season (Table 2). However, the shank provided greater projected area and surface area of roots. In the 2014/15 crop season, the use of shanks and deep tillage presented greater root length, projected area, surface area, 
Table 2 - Length (L), projected area (PA), surface area (SA), average diameter (AD), the number of forks (F), root volume (V) and number of roots tips (NT) of the 'BMX Tornado RR' soybean cultivar according to the planting management systems. Santa Maria, RS Brazil. 2015.

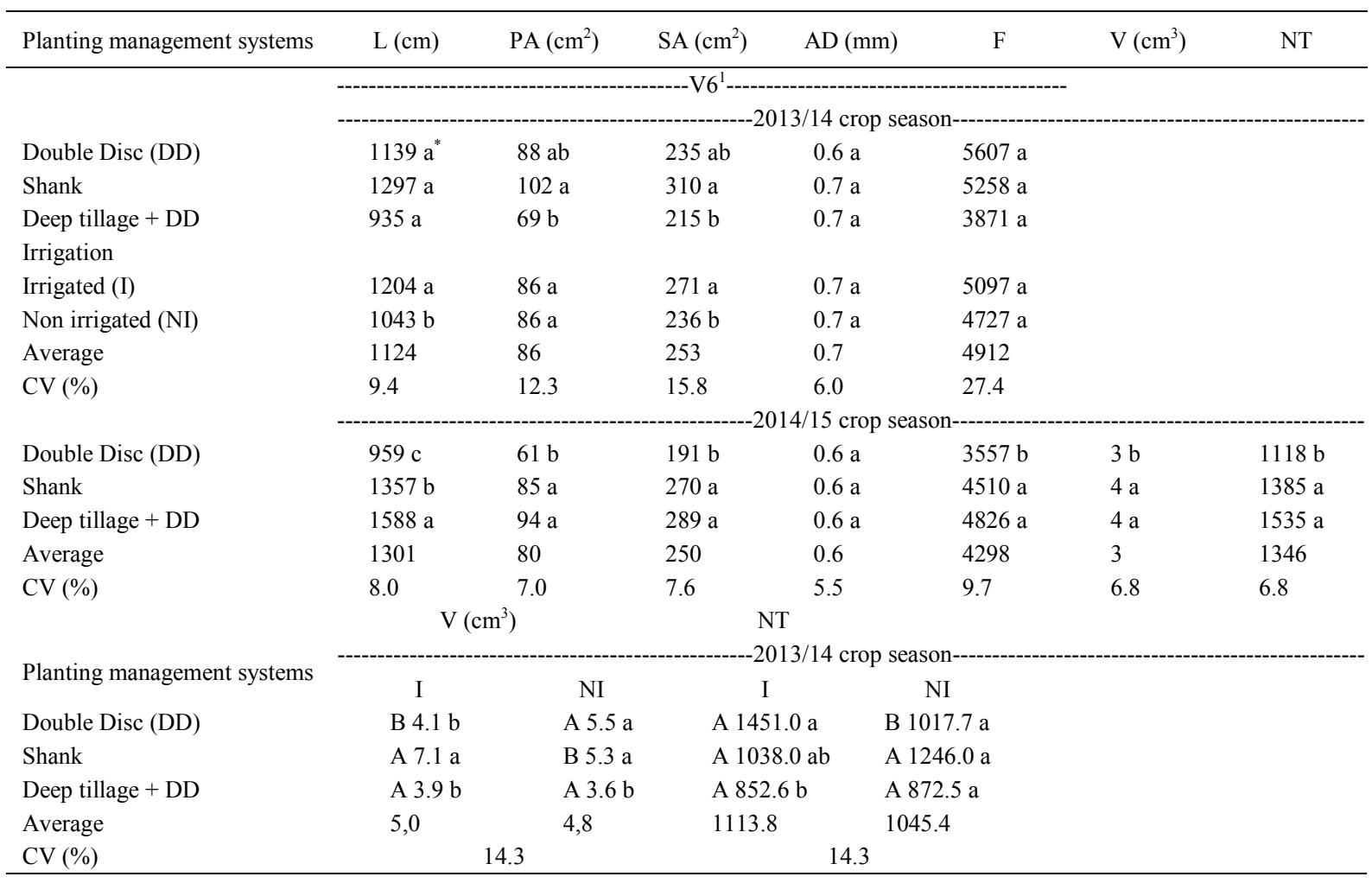

${ }^{*}$ Means preceded by the same capital letter in line and followed by same letter in the column do not differ by Tukey test at $5 \%$ probability. ${ }^{1}$ plant development stage.

number of forks, volume and number of root tips in relation to the double disc; no difference was found as to the average diameter of roots.

In the evaluation carried out in R3 (Table 3), 2013/14 crop season, the use of shank and deep tillage provided the best results in root length, projected area, surface area and number of root tips. However, at this stage there was an increase in average root diameter for the double disc system. According to SILVA \& ROSOLEM (2002), increase in root diameter and decrease in root length are among the morphological changes that can occur in roots as a result of growth restriction. According to FOLONI et al. (2006), the increase in diameter occurs as a means to increase the force exerted in the stretching process of the root meristem cells to penetrate compacted soil. In the 2014/15 crop season a positive effect was also observed for both of the mentioned parameters in systems with shank and deep tillage, no significant differences were reported for the other evaluated parameters.
Generally, according to the results reported for root growth and development in three growth stages (V6, R3 and R5), in the 2013/14 and 2014/15 crop seasons, sowing with shank and deep tillage provided greater root growth and development for soybeans grown in lowland area. This can be explained by the greater effect of these types of management in increasing the total porosity and soil macroporosity, in addition to the reduction of soil penetration resistance at the sowing line, as aforementioned. According to CARDOSO et al. (2006), the root system benefits from increased oxygenation capacity and water infiltration into the soil, features that possibly have been improved in these two planting management systems. Additionally, irrigation should be noted because the soybean root system is influenced by the water content (HOSSNE et al., 2015). In this study, except for a period of 15 days there was no rainfall in the 2013/14 crop season, 55mm irrigation in V4 plant growth stage resulted in higher root surface area and 
Table 3 - Length (L), projected area (PA), surface area (SA), average diameter (AD), the number of forks (F), volume (V) and number of root tips (NT) of the 'BMX Tornado RR' soybean cultivar according to the planting management systems and irrigation. Santa Maria, RS - Brazil. 2015.

\begin{tabular}{|c|c|c|c|c|c|c|c|}
\hline Planting management systems & $\mathrm{L}(\mathrm{cm})$ & $\mathrm{PA}\left(\mathrm{cm}^{2}\right)$ & $\mathrm{SA}\left(\mathrm{cm}^{2}\right)$ & $\mathrm{AD}(\mathrm{mm})$ & $\mathrm{F}$ & $\mathrm{V}\left(\mathrm{cm}^{3}\right)$ & NT \\
\hline & \multicolumn{7}{|c|}{ 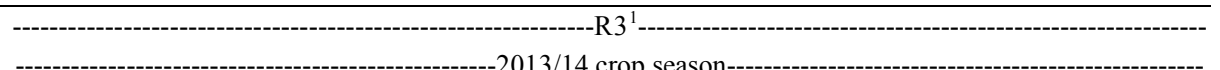 } \\
\hline Double Disc (DD) & $1418 b^{*}$ & $168 \mathrm{~b}$ & $519 \mathrm{~b}$ & $1.1 \mathrm{a}$ & 8531 a & $14 \mathrm{a}$ & $1660 \mathrm{~b}$ \\
\hline Shank & $1991 \mathrm{a}$ & $215 \mathrm{a}$ & $678 \mathrm{a}$ & $1.0 \mathrm{~b}$ & $10580 \mathrm{a}$ & $17 \mathrm{a}$ & $1986 \mathrm{a}$ \\
\hline Deep tillage + DD & $1878 \mathrm{a}$ & $189 \mathrm{ab}$ & $546 \mathrm{ab}$ & $0.9 \mathrm{~b}$ & $10234 \mathrm{a}$ & $16 \mathrm{a}$ & $2173 a$ \\
\hline \multicolumn{8}{|l|}{ Irrigation } \\
\hline Irrigated $(\mathrm{I})$ & $1710 \mathrm{a}$ & $187 \mathrm{a}$ & $605 \mathrm{a}$ & $1.09 \mathrm{a}$ & $10321 \mathrm{a}$ & $17 \mathrm{a}$ & $1810 \mathrm{a}$ \\
\hline Non irrigated (NI) & $1815 \mathrm{a}$ & $195 \mathrm{a}$ & $557 \mathrm{~b}$ & $1.04 \mathrm{a}$ & $9243 \mathrm{a}$ & $15 \mathrm{~b}$ & $2069 \mathrm{a}$ \\
\hline Average & 1762 & 191 & 3087 & 1.06 & 9782 & 16 & 1939 \\
\hline \multirow[t]{2}{*}{$\mathrm{CV}(\%)$} & 21.3 & 24.8 & 14.4 & 11.7 & 31.8 & 28.4 & 24.9 \\
\hline & \multicolumn{7}{|c|}{---2014/15 crop season--------- } \\
\hline Double Disc (DD) & 2526 a & $169 \mathrm{a}$ & $506 \mathrm{~b}$ & $0.6 \mathrm{a}$ & $9154 \mathrm{a}$ & $8 \mathrm{~b}$ & 3233 a \\
\hline Shank & 3548 a & $242 \mathrm{a}$ & $760 \mathrm{ab}$ & $0.7 \mathrm{a}$ & $13477 \mathrm{a}$ & $13 \mathrm{a}$ & $3900 \mathrm{a}$ \\
\hline Deep tillage + DD & 3638 a & $238 \mathrm{a}$ & $772 \mathrm{a}$ & $0.6 \mathrm{a}$ & $13520 \mathrm{a}$ & $12 \mathrm{a}$ & $4231 \mathrm{a}$ \\
\hline Average & 3237 & 216 & 679 & 0.6 & 12050 & 11 & 3788 \\
\hline CV $(\%)$ & 25.3 & 20.7 & 20.6 & 5.1 & 28.5 & 14.9 & 22.7 \\
\hline
\end{tabular}

${ }^{*}$ Means followed by the same letter in the column do not differ by Tukey test at $5 \%$ probability.

${ }^{1}$ plant development stage.

volume; in other periods and in the 2014/15 crop season there was balanced distribution of rainfall (Figure 1C, D), with no need for irrigation, rainfall alone was sufficient to prevent water deficits and possibly impact the root growth. In Iran, MASOUMI et al. (2014), evaluating levels of water deficit in five soybean cultivars, found decreased root length and volume. According to MASOUMI et al. (2014), this is due to the imbalance in the allocation of photosynthetic substances throughout the roots.

In this sense, it is evident that the presence of a compacted layer located close to the soil surface is a limiting factor for the growth and development of the soybean root system in lowland areas. Thus, loosening part of this compacted layer, especially the top layer, up to a depth of $15 \mathrm{~cm}$, which concentrates greater volume of roots, is a key practice in order to promote better root growth.

\section{CONCLUSION}

Planting management systems using shank and deep tillage in lowland areas provide greater root growth of soybean plants grown in these areas. An additional irrigation of $55 \mathrm{~mm}$ at $\mathrm{V} 4$ growth stage of soybean plants provides increased surface area and root volume when soil moisture reaches values below $60 \%$ of area field capacity lowland areas.

\section{ACKNOLEDGEMENTS}

We would like to thank the Coordenação de Aperfeiçoamento de Pessoal de Nivel Superior (CAPES) for providing the first author with a fellowship. We acknowledge the Conselho Nacional de Desenvolvimento Cientıfíco e Tecnológico $(\mathrm{CNPq})$ for providing a research fellowship for the second author and doctoral studies Grant for the first author and Fundação de Amparo à Pesquisa do Estado do Rio Grande do Sul (FAPERGS) for providing the fellowship scholarship to the third author.

\section{REFERENCES}

BEULTER, A.N.; CENTURION, J.F. Effect of soil compaction in root development and in soybean yield. Pesquisa Agropecuária Brasileira, v.39, n.6, p.581-588, 2004. Available from: <http:// www.scielo.br/scielo.php? script $=$ sci_arttext\&pid $=$ S0100204X2004000600010>. Accessed: Oct. 18, 2014. doi: 10.1590/ S0100-204X2004000600010.

BORGES, J.R. et al. Resistance to penetration of a typical endoaqualf submitted to tillage systems and crops. Revista Brasileira de Agrociência, v.10, n.1, p.83-86, 2004. Available from: <http://periodicos.ufpel.edu.br/ojs2/index. php/CAST/article/view/681/678>. Accessed: Oct. 18, 2014. doi: 10.18539/CAST.V10I1.681.

BORTOLUZZI, E.C. et al. Soybean root growth and crop yield in reponse to liming at the beginning of a no-tillage system. Revista Brasileira de Ciência do Solo, v.38, n.1, p.262-271, 2014. Available from: <http://www.scielo.br/scielo.php?pid=S010006832014000100026\&script $=$ sci_arttext $>$. Accessed: Oct. 18, 2014. doi: $10.1590 /$ S0100-06832014000100026. 
BOTTA, G.F. et al. Tillage and traffic effects (planters and tractors) on soil compaction and soybean (Glycine max L.) yields in Argentinean pampas. Soil \& Tillage Research, v.110, n.1, p.167-174, 2010. Available from: <http://www. sciencedirect.com/science/article/pii/S0167198710001157>. Accessed: Oct. 18, 2014. doi: 10.1016/j.still.2010.07.001.

CARDOSO, E.G. et al. Soybean root system in function of soil compaction under no-tillage system. Pesquisa Agropecuária Brasileira, v.41, n.3, p.493-501, 2006. Available from: $<$ http:// www.scielo.br/scielo.php? script $=$ sci_arttext\&pid $=\mathrm{S} 0100$ 204X2006000300017>. Accessed: Oct. 18, 2014. doi: 10.1590/S0100-204X2006000300017.

DRESCHER, M.S. et al. Persistence of mechanical interventions effect for soil decompaction in no-tillage systems. Revista Brasileira de Ciência do Solo, v.35, n.5, p.1713-1722, 2011. Available from: $<$ http://www.scielo.br/scielo.php?script=sci_abstract\&pid=S0100$06832011000500026 \& \operatorname{lng}=p t \& n r m=i s o \& t \operatorname{lng}=p t>$. Accessed: Oct. 18, 2014. doi: 10.1590/S0100-06832011000500026.

EMPRESA BRASILEIRA DE PESQUISA AGROPECUÁRIA (EMBRAPA). Indicações técnicas para a cultura da soja no Rio Grande do Sul e em Santa Catarina, safras 2012/2013 e 2013/2014. In: REUNIÃO DE PESQUISA DE SOJA DA REGIÃO SUL, 39., 2012, Passo Fundo, RS. Anais... Passo Fundo: Reunião de Pesquisa de Soja da Região Sul, 2012. 142p.

FEHR, W.R.; CAVINESS, C.E. Stages of soybean development. Ames: State University of Science and Technology, 1977. 11p. (Special report, 80).

FOLONI, J.S.S. et al. Shoot and root growth of soybean and cover crops as affected by soil compaction. Revista Brasileira de Ciência do Solo, v.30, p.49-57, 2006. Available from: $<$ http://www.scielo.br/scielo.php?pid=S0100$06832006000100006 \&$ script $=$ sci_arttext $>$. Accessed: Oct. 18, 2014. doi: 10.1590/S0100-06832006000100006.

HOSSNE, G.A. et al. Soil irrigation frequencies, compaction, air porosity and shear stress effects on soybean root development. Acta Universitaria, v.25, n.1, p.22-30, 2015. Available from: <http:// www.scielo.org.mx/pdf/au/v25n1/v25n1a3.pdf $>$. Accessed: Oct. 18, 2014. doi: 10.15174/au.2015.676.
MASOUMI, H. et al. Effects of different levels of water deficit stresses on the morphologic properties of root, antioxidants activity and the seed yield in five cultivars of soybean (Glycine $\max$ L). International Journal of Agriculture Innovations and Research, v.3, n.2, p.2319-1473, 2014.

NUNES, M.R. et al. Mitigation of clayey soil compaction managed under no-tillage. Soil \& Tillage Research, v.148, p.119-126, 2015. Available from: <http://www.sciencedirect. com/science/article/pii/S0167198714002724>. Accessed: Oct. 18, 2014. doi: 10.1016/j.still.2014.12.007.

OLIVEIRA, P.R. de et al. Physical quality of an oxisol under soybean at different compaction and irrigation levels. Revista Brasileira de Ciências do solo, v.36, p.587-597, 2012.

QUeIRoZ-VOltan, R.B. et al. Pesquisa Agropecuária Brasileira, v.35, n.5, p.929-938, 2000. Available from: $<$ http://www.sciencedirect.com/science/article/pii/ S0167198714002724>. Accessed: Oct. 18, 2014. doi: 10.1016/j.still.2014.12.007.

SILVA, R.H.; ROSELEM, C. Soybean root growth as affected by previous crop and soil compaction. Pesquisa Agropecuária Brasileira, v.37, n.6, p.855-860, 2002. Available from: <http:// www.scielo.br/scielo.php?script $=$ sci arttext\&pid $=\mathrm{S} 0100$ 204X2002000600015>. Accessed: Oct. 18, 2014. doi: 10.1590/ S0100-204X2002000600015.

SOIL SURVEY STAFF. Keys to soil taxonomy. 12.ed. Washington: United States Department of Agriculture. Natural Resources Conservation Service, 2014. 372p.

SPERA, S.T. et al. Effect of crop production systems and pastures under no-tillage on some physical attributes of soil. Revista Brasileira de Ciências Agrárias, v.7, n.3, p.388-393, 2012.

VALICHESKI, R.R. et al. Growth of cover crops and soybean yield according to physical attributes in compacted soil. Revista Brasileira de Engenharia Agrícola e Ambiental, v.16, n.9, p.969-977, 2012. Available from: <http://www.scielo.br/scielo. php?script=sci_arttext\&pid $=\mathrm{S} 0100-06832012000200028>$. Accessed: Oct. 18, 2014 . doi: 10.1590/S010006832012000200028 . 